https://journal.uwgm E-ISSN : 2549-5755

Juni 2019, Vol. 3 No. 02

\begin{tabular}{|c|c|c|}
\hline Received: March 2019 & Accepted: April 2019 & Published: Juni 2019 \\
\hline \hline \multicolumn{2}{|c|}{ Article DOI: http://dx.doi.org/10.24903/jam.v3i2.491 } \\
\hline
\end{tabular}

\title{
Evaluasi Tugas dan Kompetensi Kader Posyandu Balita di Kelurahan Jawa Kota Samarinda
}

\author{
Aprilia Nuryanti \\ STIKES Dirgahayu Samarinda \\ aprilnuryanti@gmail.com \\ Made Ermayani \\ STIKES Dirgahayu Samarinda \\ emasastrawan@gmail.com
}

\begin{abstract}
Abstrak
Pemerintah menyelenggarakan program kesehatan anak melalui Puskesmas. Puskesmas memiliki wilayah binaan kesehatan anak berupa Posyandu Balita. Puskesmas memiliki kaderkader kesehatan anak di masing-masing Pada pelaksanaannya di lapangan tugas kader tidak optimal dan menemukan beberapa kendala. Kendala yang terjadi mungkin dapat menyebabkan pencapaian program yang diharapkan oleh Puskesmas dan pemerintah kurang optimal. Oleh sebab itu, perlu penelusuran evaluasi tugas kader kesehatan anak dalam melaksanakan program kesehatan anak melalui puskesmas sebagai tangan panjang pemerintah. Evaluasi bermanfaat untuk mengembangkan pelatihan dan penyuluhan yang diperlukan bagi para kader untuk meningkatkan kompetensi mereka. Diskusi kelompok terarah dengan kader adalah salah satu upaya menelusuri dan mengevaluasi pelaksanaan tugas yang telah dilakukan kader kesehatan anak serta menemukan kendala-kendala teknis selama melaksanakan tugasnya. Hasil diskusi dianalisis dan ditarik tema-tema yang menjadi isu strategis evaluasi tugas kader kesehatan anak. FGD diikuti oleh 16 partisipan dan dua orang Pembina dari Puskesmas. Hasil FGD menunjukkan bahwa pelaksanaan tugas administrasi kader dapat dilakukan dengan baik, pelaporan dan sosialisasi program dari Pemerintah disampaikan kepada kader melalui pertemuan di Puskesmas. Kendala yang terjadi selama kader bertugas di Posyandu adalah keterbatasan jumlah kader karena ada kader kesehatan anak yang merangkap sebagai kader kesehatan lansia. Karena jumlah yang kurang maka tugas dua meja harus dilakukan oleh seorang kader sehingga ada penugasan yang dobel. Kader mengatakan masalah di lapangan lainnya adalah kurangnya kepercayaan orang tua kepada kader karena keterbatasan kader dalam pengetahuan gangguan tumbuh kembang anak dan kurang terbukanya/ penolakan orang tua untuk membawa anak ke Posyandu.
\end{abstract}

Kata Kunci: Tugas Kader, Posyandu, Balita 


\section{(A) ABDIMAS}

https://journal.uwgm.ac.id/index.php/abdimasmahakam

E-ISSN : 2549-5755

Juni 2019, Vol. 3 No. 02

\section{Pendahuluan}

Data dari Dinas Kesehatan Kota Samarinda pada tahun 2015 mencatat di Kecamatan Samarinda Ulu terdapat lima (5) rumah sakit, satu (1) rumah sakit bersalin, tiga (3) Puskesmas, 13 Klinik/ Balai Pengobatan dan 75 Posyandu. Masyarakat memanfaatkan fasilitas pelayanan kesehatan terdekat yaitu Puskesmas Pasundan yang membawahi daerah binaan untuk Kecamatan Samarinda Ulu. Letak Puskesmas Pasundan ini berada di wilayah Kelurahan Jawa. Jumlah balita (0-4 tahun) pada tahun 2015 di Kota Samarinda adalah 84.756 jiwa atau 10,43\% dari keseluruhan jumlah penduduk. Jumlah ini adalah jumlah kelompok umur tertinggi kedua setelah usia 25-29 tahun (Badan Pusat Statistik, 2015).

Pelayanan kesehatan bayi, anak balita dan prasekolah diatur dalam Peraturan Menteri Kesehatan RI nomor 25 tahun 2014. Pemantauan tumbuh kembang balita menjadi hal penting untuk dilakukan dalam pasal 23. Pemantauan pertumbuhan, perkembangan, dan gangguan tumbuh kembang sebagaimana dimaksud pada ayat (1) harus diselenggarakan secara komprehensif dan berkualitas melalui kegiatan: a. stimulasi yang memadai; b. deteksi dini penyimpangan tumbuh kembang; dan c. intervensi dini penyimpangan tumbuh kembang. Kegiatan sebagaimana dimaksud pada ayat (2) dilakukan di fasilitas pelayanan kesehatan dasar dan di taman kanak-kanak. Oleh karena hai itu keberadaan fasilitas pelayanan kesehatan dasar dalam hal ini Puskesmas sebagai penggerak pemberdayaan masyarakat melalui Posyandu menjadi tolok ukur pelaksanaan Peraturan Menteri Kesehatan tersebut (Menteri Kesehatan Republik Indonesia, 2014).

Jumlah Posyandu sebanyak 75 buah di Kecamatan Samarinda Ulu ini menjadi perhatian khusus (Kementrian Kesehatan RI, 2013). Puskesmas memiliki kader-kader kesehatan anak di masing-masing. Puskesmas memiliki kader-kader kesehatan anak di masing-masing Posyandu yang seharusnya memiliki bekal pengetahuan dan keterampilan dalam deteksi dini, pemantauan tumbuh kembang dan kesehatan anak, tidak hanya secara administratif melakukan pekerjaan dalam kegiatan Posyandu. Pada pelaksanaannya di lapangan tugas kader tidak optimal dan menemukan beberapa kendala. Kendala yang terjadi mungkin dapat menyebabkan pencapaian program yang diharapkan oleh Puskesmas dan pemerintah kurang optimal. Oleh sebab itu, perlu penelusuran evaluasi tugas kader kesehatan anak dalam melaksanakan program kesehatan anak melalui puskesmas sebagai tangan panjang pemerintah. Evaluasi bermanfaat untuk mengembangkan pelatihan dan penyuluhan yang diperlukan bagi para kader untuk meningkatkan kompetensi mereka.

Kendala yang terjadi selama kader bertugas di Posyandu adalah keterbatasan jumlah kader karena ada kader kesehatan anak yang merangkap sebagai kader kesehatan lansia. Jika seyogyanya kader petugas Posyandu masing-masing menduduki lima meja, namun karena jumlah kader yang kurang maka tugas dua meja harus dilakukan oleh seorang kader sehingga ada penugasan yang dobel. Materi tentang tumbuh kembang anak disampaikan oleh Puskesmas melalui Buku Panduan Kader, di mana pemantauan tumbuh kembang dilakukan dengan Deteksi Dini Tumbuh Kembang (DDTK). Namun, pada kenyataannya tidak semua kader pernah mendapat materi sosialisasi mengenai topik tersebut. Kader mengatakan masalah di lapangan lainnya adalah kurangnya kepercayaan orang tua kepada kader dan kurang terbukanya/ penolakan orang tua untuk membawa anak ke Posyandu. 
https://journal.uwgm.ac.id/index.php/abdimasmahakam

E-ISSN : 2549-5755

Juni 2019, Vol. 3 No. 02

Puskesmas dapat secara bersinergi bekerja sama dengan institusi kesehatan yang mempunyai perhatian pada kesehatan anak, seperti yang diusung dalam Program Kemitraan Masyarakat oleh STIKES Dirgahayu Samarinda. Institusi pendidikan tinggi kesehatan sudah seharusnya membina dan meningkatkan status kesehatan masyarakat di area wilayah kerjanya. Melalui kerjasama dengan Puskesmas maka kegiatan peningkatan kompetensi bagi kader kesehatan dapat dilakukan.

\section{Metode}

Metode pendekatan yang dilakukan oleh pengusul berupa diskusi kelompok terarah. Daftar pertanyaan telah disiapkan sebelumnya terkait dengan evaluasi tugas kader kesehatan anak. Pencatatan proses diskusi dilakukan oleh notulen. Perekaman menggunakan alat perekam juga dilakukan dan dimintakan ijin kepada partisipan. Catatan isu penting selama diskusi juga dibuat dan dilaporkan. Pengusul melibatkan mahasiswa sebagai asisten pengambil data yaitu bertugas mengoperasikan alat perekam dan membantu secara teknis kelancaran diskusi.

Penangung jawab kader dari puskesmas melakukan sosialisasi undangan dari pengusul bagi para kader. Kader kesehatan anak secara langsung berhubungan dengan pengusul dalam menentukan jadwal kegiatan dan partisipan yang mengikuti kegiatan. Masing-masing Posyandu mengirimkan perwakilannya dalam kegiatan ini.

Diskusi kelompok diikuti oleh kader-kader Posyandu Balita dan Pendamping dari Puskesmas pada tanggal 15 Agustus 2018 bertempat di Griya Sehat Bayi dan Balita yang merupakan unit usaha STIKES Dirgahayu Samarinda beralamat di Jalan K.S Tubun Dalam No. 30B kota Samarinda.

Evaluasi program dilakukan sebagai berikut:

1) Evaluasi kegiatan akan dilakukan setelah kegiatan selesai dilakukan berupa laporan kegiatan

2) Keberlanjutan program ditentukan bersama antara pengusul dan seluruh mitra. Mitra meminta pengusul untuk memberikan penyuluhan tentang tumbuh kembang balita, metode pemeriksaannya dan materi pendidikan kesehatan anak.

\section{Hasil dan Pembahasan}

FGD melibatkan kader posyandu balita, pembina kader posyandu balita tentang Evaluasi Tugas Kader Posyandu Balita dan menggali kebutuhan peningkatan pendidikan kesehatan dan pelatihan bagi para kader. FGD dilaksanakan pada hari Rabu, 15 Agustus 2018 pukul 09.00 - 11.00 yang dihadiri oleh 16 orang kader posyandu balita dan 2 pembina kader posyandu dari Puskesmas Pasundan. 
https://journal.uwgm.ac.id/index.php/abdimasmahakam

E-ISSN : 2549-5755

Juni 2019, Vol. 3 No. 02

\section{Foto 1 Kegiatan FGD}
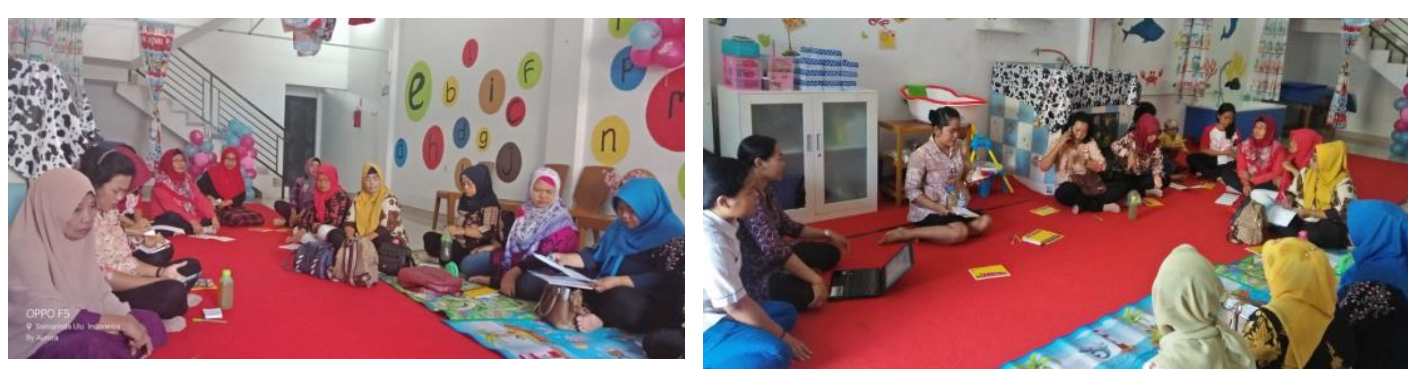

Hasil dari FGD meliputi:

\begin{tabular}{|c|c|c|}
\hline No & Isu & Hasil Diskusi \\
\hline 1 & $\begin{array}{l}\text { Tugas Administrasi } \\
\text { Kader }\end{array}$ & $\begin{array}{l}\text { a. Tugas administrasi kader dilakukan dengan } \\
\text { membuat laporan kegiatan dan isian formulir hasil } \\
\text { kegiatan Posyandu Balita. } \\
\text { b. Pelaporan dilakukan pada saat pertemuan bulanan } \\
\text { di Puskesmas. } \\
\text { c. Kader posyandu mengatakan mengalami kesulitan } \\
\text { pencatatan terkait dengan format pencatatan yang } \\
\text { kecil }\end{array}$ \\
\hline
\end{tabular}

2 Tugas Teknis Kader

a. Kesulitan pada penimbangan yang terkait dengan peralatan dan kondisi anak;

b. Kesulitan jika orang tua balita langsung melakukan konsultasi kepada kader;

c. Kader posyandu merasa belum bisa menyampaikan edukasi atau konseling kepada orang tua balita

3 Kompetensi Kader

a. Kader posyandu balita sudah mendapatkan pengetahuan dan pelatihan mengenai pelaksanaan pelayanan posyandu 5 meja namun perlu dilakukan refresh pada materi meja ke-3

b. Pelatihan lainnya yang pernah diadakan terkait dengan topik tumbuh kembang yaitu materi pemeriksaan tumbuh kembang balita dengan Deteksi Dini Tumbuh kembang (DDTK) yang terdapat dalam buku Panduan Kader dan pernah dilakukan pelatihan namun belum seluruh kader mengikutinya

c. Kurangnya kepercayaan orang tua kepada kader karena keterbatasan kader dalam pengetahuan gangguan tumbuh kembang anak dan 


\begin{tabular}{cc}
\hline lainnya & membawa anak ke Posyandu \\
Tabel 1Tabel Isu Strategis Hasil Diskusi Kelompok Terarah dengan Kader Posyandu Balita di \\
Kelurahan Jawa
\end{tabular}

Puskesmas adalah unit pelaksana teknis Dinas Kesehatan Kabupaten/Kota yang bertanggung jawab melaksanakan pembangunan kesehatan di kecamatan. Kedudukan Posyandu terhadap Puskesmas adalah sebagai wadah pemberdayaan masyarakat di bidang kesehatan yang secara teknis medis dibina oleh Puskesmas .

Upaya peningkatan peran dan fungsi Posyandu bukan semata-mata tanggungjawab pemerintah saja, namun semua komponen yang ada di masyarakat, termasuk kader. Peran kader dalam penyelenggaraan Posyandu sangat besar karena selain sebagai pemberi informasi kesehatan kepada masyarakat juga sebagai penggerak masyarakat untuk datang ke Posyandu dan melaksanakan perilaku hidup bersih dan sehat. Posyandu (Pos Pelayanan Terpadu) merupakan salah satu bentuk Upaya Kesehatan Bersumberdaya Masyarakat (UKBM) yang dilaksanakan oleh, dari dan bersama masyarakat, untuk memberdayakan dan memberikan kemudahan kepada masyarakat guna memperoleh pelayanan kesehatan bagi ibu, bayi dan anak balita.

Sistem Informasi Posyandu (SIP) bergantung pada ketelitian kader dalam mencatat formulirformulir. Pada posyandu balita berikut yang harus dilaporkan: catatan pemberian vitamin A, pemberian oralit, pemberian tablet tambah darah bagi ibu hamil, tanggal dan status pemberian imunisasi. Format SIP meliputi; catatan ibu hamil, kelahiran, kematian bayi, kematian ibu hamil, melahirkan, nifas; catatan bayi dan balita yang ada di wilayah kerja Posyandu; jenis kegiatan yang tepat dan sesuai dengan kebutuhan sasaran (Kemenkes, 2012). Oleh sebab itu, kader sebagai ujung tombak dan penggerak Posyandu sudah selayaknya memiliki kompetensi dalam menjalankan program-programnya. Namun demikian tugas administrasi kader tidak dipungkiri memang tidak sedikit. Kompleksitas laporan juga membutuhkan kemauan, ketelitian dan daya juang dalam menyelesaikannya. Dukungan kuat dari berbagai pihak secara moril, materil dan finansial diperlukan demi keberhasilan pengelolaan Posyandu. Kerjasama dan pengabdian para pengelola termasuk kadernya diperlukan (Kemenkes, 2012).

\section{Simpulan dan rekomendasi}

Kader posyandu balita sudah mendapatkan pengetahuan dan pelatihan mengenai pelaksanaan pelayanan posyandu 5 meja. Namun ditemukan beberapa kesulitan dalam pelaksanaannya yaitu: kesulitan pada penimbangan yang terkait dengan peralatan dan kondisi anak; kesulitan pencatatan terkait dengan format pencatatan yang kecil, kesulitan jika orang tua balita langsung melakukan konsultasi kepada kader; dan kader posyandu merasa belum bisa menyampaikan edukasi atau konseling kepada orang tua balita

Secara umum tugas administrasi kader kesehatan anak dapat menjalankan tugasnya dalam pelaporan tiap bulan ke Puskesmas. Ada kebutuhan peningkatan pengetahuan dan 


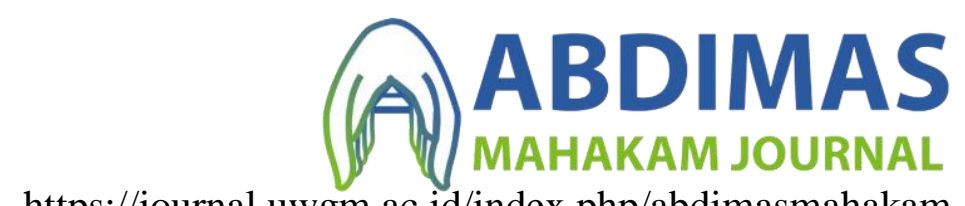

https://journal.uwgm.ac.id/index.php/abdimasmahakam

E-ISSN : 2549-5755

Juni 2019, Vol. 3 No. 02

keterampilan bagi kader untuk memfasilitasi kebutuhan masyarakat akan edukasi terkait tumbuh kembang dan masalah kesehatan pada anak. 
https://journal.uwgm.ac.id/index.php/abdimasmahakam

\section{(A) ABDIMAS MAHAKAM JOURNAL}

E-ISSN : 2549-5755

Juni 2019, Vol. 3 No. 02

\section{Daftar Pustaka}

Badan Pusat Statistik (2015). Data Kependudukan . Samarinda: BPS Kota Samarinda.

Badan Pusat Statistik (2015). Jumlah Fasilitas Kesehatan Menurut Kecamatan di Kota Samarinda. Samarinda: BPS Kota Samarinda.

Kementerian Kesehatan RI (2013). Riset Kesehatan Dasar . Jakarta: Kementerian Kesehatan RI.

Kementerian Kesehatan RI (2012). Buku Pegangan Kader Posyandu. Jakarta: Depkes RI.

Menteri Kesehatan Republik Indonesia. (2014). Peraturan Menteri Kesehatan Rebuplik Indonesia Nomor 25 Tahun 2014 tentang Upaya Kesehatan Anak. Jakarta: Kementerian Kesehatan RI. 